\title{
Nigerians' Reactions towards COVID-19 Pandemic Health Precautions: A Pragma-Semiotic Analysis
}

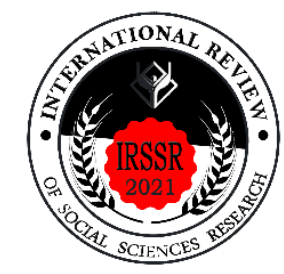

\section{Festus Moses Onipede}

\begin{abstract}
After the Federal Government of Nigeria declared a total lockdown and COVID-19 pandemic health precautions, many Nigerians have gone to their various Facebook walls to show their reactions. These were deployed via texts (captions) and visual (photos) means. Previous studies on COVID-19 pandemic in Nigeria have adopted critical discourse analysis and stylistics approaches with little attention paid to pragmatic and multimodal reactions of the Nigerians towards COVID-19. This paper undertakes pragma-semiotic analysis of the Nigerians' reactions towards COVID-19 pandemic health precautions to examine how the texts and images portray their intentions towards COVID-19, to discover the potential meaning exhibited by the images and captions, and to analyse the pragmatic acts of the linguistic and nonlinguistic posts. Sixteen Nigerian Facebook posts were purposively selected using insights from Mey's (2001) pragmatic act and Kress and van Leeuwen's (2006) multimodal discourse analysis. The posts which were classified under four semantic fields namely business innovation and profit-oriented, law abiding, poverty striking and satirical posts have various visual-pragmatic strategies such as creativity, obedience, complacency, begging and ridicule. The use of pictures and texts in Facebook to tell stories about Nigerians' reaction towards Corona virus pandemic is a demonstration of ethical responsibility that has great implications for public peace especially in an African country like Nigeria with pandemic concerns.
\end{abstract}

Keywords:

COVID-19, pandemic, health, pragmatics, multimodal, captions

Suggested Citation: Festus Moses Onipede (2021). Nigerians' Reactions towards COVID-19 Pandemic Health Precautions: A Pragma-Semiotic Analysis. International Review of Social Sciences Research, Volume 1, Issue 1, pp. 1- 24.

About the author:

Lecturer, Department of English, University of Lagos, Akoka, Nigeria 


\section{Introduction}

Etymologically, COVID-19 pandemic, which has 'CO' for Corona, 'VI' for virus, 'D' for disease, '19' for year, was initially referred to as corona virus or 2019n-cov. It is a pathogenic viral infection caused by Severe Acute Respiratory Syndrome Corona virus2 (SARS-COV-2). The pandemic originated from Wuhan city specifically from the Huana Seafood Market. According to Tan (2020), the pandemic was suspected to come from bats or pangolins and spread to men, as it was spread to different parts of the world including Singapore, Malaysia, USA, Korea, Iran, Japan and Philippines to mention a few. It has rapidly impacted over 200 countries, areas and territories. On April 19, 2020, the World Health Organisation (WHO) confirmed 2,241,359 COVID-19 cases, with 152,551 deaths. The outbreak of COVID-19 pandemic has led to various forms of communication in the cyber world. The internet makes it possible for the Nigerians to communicate their minds quickly in the virtual space.

Social media has become an important source to create awareness on the outbreak of the pandemic. In fact, after the Federal Government declaration of 14 days lockdown on March 30, 2020 and the compulsory face mask use in public on April 25, 2020, there have been lots of reactions from Nigerians in their various social media posts. There are social media posts that had gone viral due to their humour and appeal to the netizens. Facebook is one of the major social media Nigerians used to post their reactions on COVID-19.

In Nigeria, Facebook has been a major platform for people to express themselves in various issues and concerns. For instance, during the period of total lockdown where Nigerians could no longer visit their loved ones, they turn to Facebook to express their reactions towards the pandemic precautions. This is the only means through which they can express their views. The Facebook posts not only include texts but also pictures that reflect their varied reactions towards the government interventions on the situation. The reactions of the Nigerians in the virtual world call for pragmatic and multimodal analysis. From this background, this paper examined the Facebook texts and the pictures associated with the pandemic.

The present study is concerned with the pragmatic and multimodal analysis of the Nigerians' reactions to COVID-19 pandemic health precautions on their Facebook wall posts. 
It aims to delve into the interpretation and meaning embedded in their posts. Specifically, the research questions answered are the following:

1. How do the texts and images portray the Nigerians' reactions towards COVID-19?

2. How are the potential meaning exhibited by the images and captions?

3. What are the pragmatic acts of the linguistic and nonlinguistic posts?

\section{Literature review}

Previous studies have focused on stylistics, critical discourse analysis and language of the COVID-19 pandemic. The existing linguistic studies centre on Covid-19 from different perspectives (Alvarez, 2020; Prieti-Ramos et al, 2021; Saudi, 2020; Anyanwu, 2020; Sasot et al, 2020; Grzelke, 2020; Oladapo \& Badamosi, 2021; Ononye \& Offor, 2021; Chinedu, 2021; Aliya, 2021; Onyema, 2021; Uwadiegwu, 2021; Priedia, 2021; Olorunsogo \& Olufaso, 2021;Uguola, 2021; Kalejaiye, 2021; Yahaya, 2021; and Ayeni, 2021). From the linguistic perspective, Alvarez (2020) examined the potential language of SARS-COV-2. He discovered that the virus may have a nonverbal and non-alphabetic language through which its virus communicate, by means of 'noises' sending orders for different behaviours.

Prieti-Ramos et al. (2020) used a socio-semiotic process to examine the practice of naming in corpus of the eight newspapers of four countries in the early stages of the disease. The finding revealed that the naming choices can carry powerful resonances of the tensions between political and technical considerations in handling a pandemic where information flows in real time and at unprecedented levels of interconnection between communication channels worldwide. The study also examined how the new virus and the disease were named by WHO, how their choices had an impact on naming patterns among the news media during the first months of the outbreak.

Saudi (2020) assessed the sociological paradigms on the spread and containment of the Corona virus in Nigeria. It was recommended that territorial imperative be observed with a high sense decorum for the sake of these generations and one yet unborn.

Anyanwu (2020) evaluated the two speeches of President Muhammad Buhari to ascertain how he has employed the language, the linguistic elements used and the stylistic 
and pragmatic imports. It was found that the President is combating the Corona virus in Nigeria.

Sasot et al. (2020) conducted a discourse analysis on the class cancellation during the COVID-19 pandemic. The study applied Foucaudian discourse analysis to understand the discourses about the cancellation of online classes, the implications of the discourses on action orientation, social practices and subjectivities. The findings showed that the major discourses highlighted the inequality in society in the context of education during the pandemic.

Moreover, Grzelke (2020) applied critical discourse analysis to the attitudes of Polish people towards the vulnerability populations in the time of Gazeta PL online comment sections. Results revealed that that elderly people are vulnerable to getting seriously ill with the COVID-19 virus and diabetes as a risk factor in becoming ill with COVID-19 virus.

From the sociological perspective, Oladapo and Badamosi (2020) investigated the attitude of rural dwellers in the South Western Nigeria towards the guidelines set up by the Government to eradicate the virus. The findings revealed that the respondents are aware of the existence of the virus but social distancing may not work in local rural areas due to their culture and the nature of the accommodation. The finding also showed that people believe that the virus is for elites in the society and that the government exaggerated the number of affected people for political and financial gain.

Ononye and Offor (2021) assessed the Nigerian media's contribution to the fear people have about the novel disease, analysed the rhetorical strategies deployed in the Nigerian government media sensitisation messages on Covid-19, and explored how strategies steer fear about corona virus in the minds of its citizens. The findings showed that a great deal of the rhetorical strategies used for the sensitisation of citizens on corona virus involve the use of interrogative clauses and illocutions while a smaller value involves directive discourse strategy.

Chinedu (2021) evaluated the vocabulary of the pandemic in Nigeria. It was discovered that to use the words or phrases correctly, the English learner has to make a conscious effort to learn their meanings in order to be able to use the vocabulary in the right context. 
Aliya (2021) examined the pragmatic stance in the four different Nigerian newspapers report to uncover the kinds of stance taken by each newspaper in relation to the pandemic and how the issue has been portrayed in each editorial. The study contributed to the discourses on Covid-19 pandemic in that it foregrounds the kinds of stance taken by the selected newspapers in relation to the propositions they make.

Onyema (2021) focused on four speeches of selected African and non-African Presidents to examine the intended meaning, appropriateness and effectiveness of the speeches to the citizens of these various countries. The selected four speeches are President Donald Trump's speech on Corona virus pandemic on March 11, 2020, Boris Johnson's address to the nation on March 23, 2020, Uhuru Kenyatta's address on March 25, 2020, and President Mohammadu Buhari's statement on the outbreak of Covid-19 on March 26, 2020. The study used insights from Austin's speech act theory to identify and explain the illocutionary functions of language used by the selected presidents. The other linguistic features that are of stylistic value were used to characterise the speeches.

Predia (2021) analysed some humorous COVID-19 memes amidst the Covid-19 pandemic and how these help to ameliorate the hardships suffered by the citizens. Data were drawn from the social media and in particular, WhatsApp platforms and examined using the multimodal discourse analytic lens. The finding showed that the mimetic modes show pragmatically that they are nested on voices (multimodal) that are compatible or divergent, as can be seen in the dissociative echoing of individuals on distancing, lockdown and quarantine as expressing their collective reactions to governments' policies on measures to contain the spread of Covid-19.

Olorunsogo \& Olufajo's (2021) paper focused on the discourse strategies deployed in the media representations and labelling of commercial sex worker during COVID-19 and their compliance with stipulated measures in place to inhibit the spread of the virus, using insights from van Dijk critical discourse analytical discourse approach. The discourse issues projecting the media representations and identities of sex workers were violation of lockdown, constituents of essential workers and commitment to curbing the spread of the virus. 
Uguola (2021) examined the intricate semiotic elements in selected Corona virus cartoons, as ways through which the dire straits situation in Nigeria is foregrounded by the cartoon creators. The study revealed how the joint semiotic elements in the cartoons draw the audience into the process of signification, using insights from Clark and Brennan's Common Ground theory (1991), and Kress and van Leeuwen's Multimodality Theory (2006). The study used selected cartoons posted on Whatsapp platforms during the lockdown in Nigeria between March 2020 and July 2020 to reveal the meanings embowelled in the cartoons. Findings revealed that images of corruption, deliberate promotion of falsehood, and embezzlement by the upper class were encoded in the cartoons. The study concluded that shared situational knowledge cue readers into drawing the right inference in order to interpret authors' messages encoded in the cartoons.

Kalejaiye (2021) investigated the politeness variance between the instruction patterns in the advertisement of native speakers as against that of non-native speakers. The study adopted qualitative research method. Three purposive Covid-19 advertisements from three different countries: Australia, Britain and Nigeria formed the sample size of the study using insights from Culpeper's Politeness and impoliteness Theory (2011). The study revealed that the instructions of the native speakers in the various advertisements were more polite than those of the non-native speakers which were mainly not mitigated.

Furthermore, Uwadiegwu (2021) examined the description of both the images and the utterances of Donald Trump and his aides as well as the press crews during the various press briefings which he entertained at the White House in March 2020 using a synthesis of the contributions of Kress and van Leeuwen (2006), Machin (2007), Royce and Bowcher (2007), Canning-Wilson (2001) and Halliday (1985), to know whether Kress and Leeuwen's vectoriality suffices in a direct speech situation such as the COVID-19 press briefings unlike in the images of the corona virus and other semiotic resources whose interpretation could be as straight forward as possible. The study revealed that the narrative representations relate the participants mentioned by Donald Trump to the contexts in terms of what they did, what happened after all or what he failed to do as the American president.

Yahaya (2021) investigated the linguistic strategies of threat construction and fear spawning in President Muhammadu Buhari's four speeches from 29th March to 22nd 
December 2020 on Covid-19 war rhetoric in Nigeria. Using Cap's (2013) Proximization theory as framework, the paper applied cognitive-pragmatic methodology in examining how the president enforced the imminence of an outside threat to claim legitimization of the preventive policies he has imposed despite their unbearable impact on the public, how he sustained the legitimacy in the various phases of the speeches despite their unbearable impact on the public, and how he sustained the legitimacy in the various phases of the speeches. The finding revealed that the best legitimisation effects were obtained by discursively constructed fear appeals, which ensure quick social mobilisation.

Ayeni (2021) examined the types of knowledge of the pandemic constructed by the different groups and the pragmatic adaptation of these knowledge bases to the Nigerian COVID-19 situation. The findings showed three basic types of knowledge deriving from international, national and local points of view: professional, folk and independentinterpreter epistemics.

Previous studies (Ayeni, 2021; Onyema, 2021; Uwadiegwu, 2021; Kalejaiye, 2021; and Aliya, 2021) on COVID-19 pandemic from the perspectives of pragmatics are similar to the present study because they investigated COVID-19 pandemic based on the context of use, but differ from the present study because the semiotic aspects of the data are not examined. Again, other studies such as Yahata, 2021; and Anyanwu, 2020 used synthesis of pragmatics, cognition and pragmatics to examine their data but their studies did not consider the semiotic content of the data. Hence, the present study sets to apply synthesis of pragmatics and semiotics.

In addition, Prieto-Ramos et al. (2020), Predia (2021) and Uguola (2021) studies are only based on multimodality or semiotics. Therefore, their studies failed to consider the context where these semiotic elements are used. Other studies such as Grzelke (2020), and Olorunsogo and Olufayo (2021) are investigated from the purview of critical discourse analysis. Also, the data for the previous studies are not taking Facebook posts.

From the review of previous studies, the researcher observed that no study has been carried out on Nigerians' reactions towards COVID-19 pandemic health precautions using synthesis of pragmatics and semiotics. This is indeed, the gap in knowledge which the 
present study has come to fill. Also, the present study adopts pragmatics and multimodal discourse analysis approaches to Nigerians' reactions in their Facebook posts towards COVID-19 pandemic. As such, this study aims to (a) examine how the texts and images portray their reactions towards COVID-19, (b) discover the meaning potential exhibited by the images and captions, and (c) examine the pragmatic acts of linguistic and nonlinguistic posts.

\subsection{Theoretical Framework}

This paper applied insights from the theories of Mey's (2001) pragmatic acts, and Kress and Van Leeuwen's (2006) multimodal discourse analysis. Mey's model of pragmatic acts is based on speech situations. It explains the way pragmemes are represented in context. Pragmatic act is against J.L Austin's speech acts which Mey considered as non-situated (Mey, 2001). Speech acts can only be effective and successful when they are situated (Mey, 2001, p. 218). The social context is very important because it considers the verbal behaviours of an individual within its affordances. This is evident in Mey's (2006, p. 758) submission that " the situation... creates the 'affordances' by which we are guided toward a correct interpretation of what we are hearing [viewing], and indeed of what we ourselves are saying [drawing]... " Here, context of situation plays a vital role for meaning potential. Mey (2001) opines that pragmeme can be executed in a general situational prototype, which can be realised through individual pragmatic acts. Pragmeme realises generalised pragmatic act and 'ipras' or 'practs' are instantiated single or individual pragmatic acts, and are realisations of a particular pragmeme. The instantiated pragmatic acts - 'ipras and practs' are called allopracts. Each of these practs is distinctly realised in different situation. Mey (2001, p. 221) puts that "what is realised as a pract under a pragmeme as an allopract of its own, is wholly determined by the understanding an interactant or individual has of the situation, and by the effects of these practs have or may in a particular context."

Meanwhile, Kress and van Leeuwen (2006) apply Halliday's (1978) meta-functions of language ideational, interpersonal and textual in their work titled "Grammar of Visual Design" (GVD). They account for both verbal and nonverbal components of multimodal texts like images, symbols, pictures, and colours. To Kress and van Leeuwen, semiotic 
language performs three (3) functions, namely; representational, organisational and compositional. The representational aspect of Kress and van Leeuwen is appropriate for this study because it is basically used to express one's experience or a vision of reality. Every image used by the interactants has a representative meaning, which can be 'amplified, exaggerated, and more than real (Kress \& van Leeuwen, 2006, p.167). Kress and Van Leeuwen application of Halliday's transitivity system suggests that the analysis of images in representational terms demands the identification of the represented participants, the process or the action described and the qualities of the participants and the circumstances in which the action is being developed.

\section{Methodology}

The study is qualitative in nature and involves descriptive analysis. The data comprise both verbal and visual (images, colour) posts from selected Nigerian's personal Facebook wall posts and Facebook Group pages, Federal Polytechnic Nekede 2019/2020 aspirants and Federal Polytechnic Ado -Ekiti. The analysis is concerned with the Pragma-semiotic elements (photos and captions).

Sixteen posts on COVID-19 pandemic were collected for analysis. The 16 posts were purposively classified into the following semantic fields: business innovation and profit oriented posts, law abiding posts, satirical posts, and poverty striking posts.

The data analysis include (1) the data were analysed qualitatively and a content analysis is carried out to identify the semantic fields of the posts; (2) a frequency analysis and tabulation of the selected pictures was done in relation to their various semantic fields and (3) a detailed qualitative pragma-semiotic analysis and interpretation using insights from Mey's (2001) pragmatic acts and Kress and van Leeuwen's (2006) GVD. The GVD accounts for visual semiotic modalities in selected Facebook posts as well as the interaction between the texts and the pictures. The selection is purposeful based on uniform perception since the posts have related thematic focus which addresses COVID-19 issues. 


\section{Findings and Discussion}

Table 1

Categorisation of Nigerians' posts towards COVID-19 Pandemic Health Precautions

\begin{tabular}{lcc}
\hline \multicolumn{1}{c}{ Types } & F & \% \\
\hline Business Innovation and profit oriented posts & 3 & 18.75 \\
Law abiding posts & 3 & 18.75 \\
Satirical posts & 8 & 50 \\
Poverty striking posts & 2 & 12.50 \\
\hline Total & $\mathbf{1 6}$ & $\mathbf{1 0 0}$ \\
\hline
\end{tabular}

The categories of the 16 Facebook posts purposively chosen are presented in Table 1. The highest of which are the satirical posts comprising $50 \%$.

Table 2

Pragmatic acts found in the data

\begin{tabular}{lccc}
\hline \multicolumn{1}{c}{ Pragmatic acts } & Data & F & \% \\
\hline Demonstrative & figures 5, 6, 10, 15 & 4 & 25 \\
Persuasive & figure 1 & 1 & 6.25 \\
Suppository & figures 2, 3, 7,8,11 & 5 & 31.25 \\
Assertive & figures $12,13,14$ & 3 & 18.75 \\
Condoling & figures 4, 9, 16 & 3 & 18.75 \\
\hline Total & & $\mathbf{1 6}$ & $\mathbf{1 0 0}$ \\
\hline
\end{tabular}

The pragmatic acts found in the 16 Facebook posts are presented in Table 2. There were more suppository acts with $31.25 \%$.

\subsection{Business Innovation and profit oriented posts}

These are posts on Nigerians' Facebook wall to show their ingenuity in terms of business. In any situation Nigerians are in, they are known to be very innovative and creative especially in dire situations where they use an opportunity to take advantage of a desperate situation in order to make money (Nnadozie, 2002).

Business innovation and profit oriented posts are photos deployed to show Nigerians' reactions towards COVID-19 pandemic health precautions. These photos show the intention 
the moment COVID-19 was declared a pandemic in Nigeria and the total lockdown in Lagos, Ogun and Abuja.

\section{Figure 1}

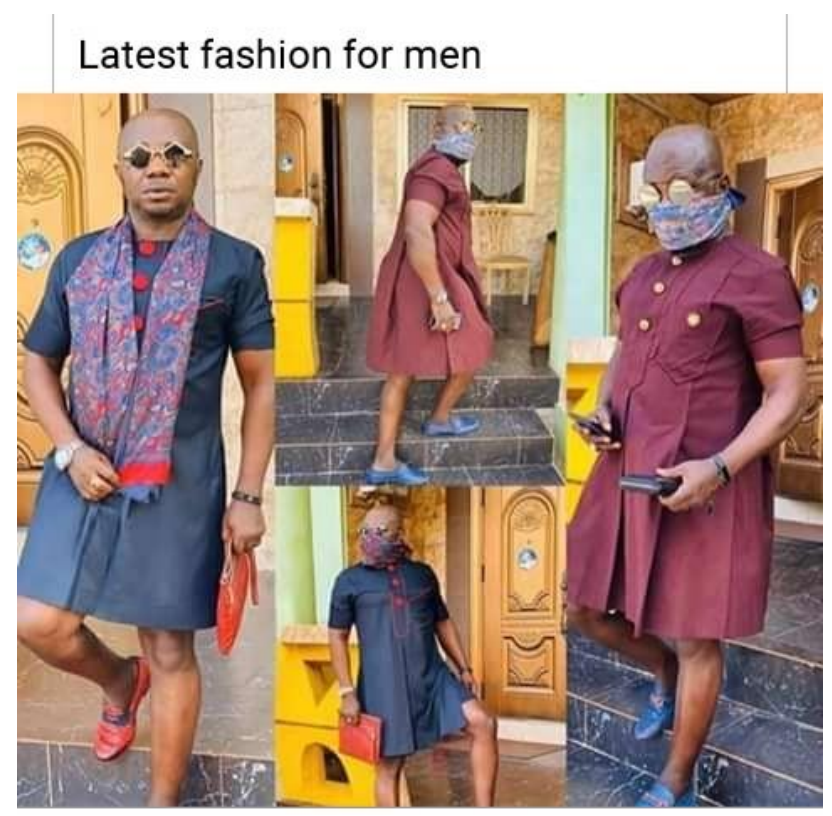

Source: funny_african_pics

In figure 1, a man is clothed with wrist watch and bangles on the right hand. He puts on spectacles and muffler on his neck. The shirt's colour is navy blue and the shoes are in colours red and red buttons. The first picture of the man shows that he is preparing to go out; the second picture presents the man with handkerchief tied on his nose and mouth, with red book diary on his right hand. The other picture showed the man as he is ascending a staircase with eyeglasses, black shoes on his legs and right hand with a mobile phone. As he ascends the staircase, he looks back. The fourth picture presents the man holding two mobile phones in his two hands, spectacles and eyeglasses, and he is descending the staircase. These pictures present different ways men can dress in this lockdown period. It shows that the designers of these outfits are displaying their skills to the public as a way of persuading people to patronise them. The caption above the pictures 'latest fashion for men' gives credence to the mode. It is therefore the intention of creative Nigerian fashion designers to make profit during the lockdown.

In the same vein, figure 2 presents a woman putting on face mask. She puts the other pack of the face masks in her left hand.

The face mask is designed in such a way that it spreads out about 2-3 feet. This is specifically designed to obey social distancing law. The caption 'Face mask available, buy two and get one free' creatively shows the seller's strategy of advertising, and a means of making quick sale. 


\section{Figure 2}

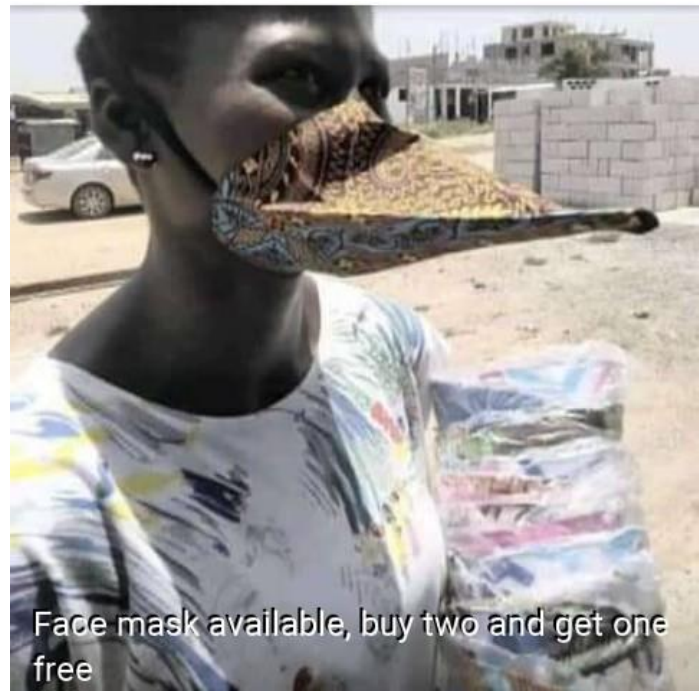

Source: Emerald Nigeria
Again, the marketing technique is used by the seller to persuade people to buy in quantity since she knows that people can buy for themselves and other people around them. The background of the face mask seller foregrounds a new building site where different kinds of building professionals such as welders, bricklayers, engineers, architects, surveyors, contractors, carpenters, aluminum workers, painters and other people meet. The face mask seller stands very close to the site to display her wares. The pragmatic act for this strategy is

persuasive.

Similarly, figure 3 presents the interior part of a supermarket, with a woman who dresses with a cap and pointed face mask together with an object which looks like a knitted basket.

\section{Figure 3}

She holds black bag in her right hand. She moves round to select what she wants to buy. The text that accompanies the picture reads: 'social distancing outfit available now. Hmm. COVID-19 SPECIAL' The caption makes the viewers understand that social distancing law should be obeyed, and this gives the supermarket customers the assurance that once they put on this outfit nobody will move closer to them. The picture therefore is performing a suppository act because it portrays the ironic situation most Nigerians find themselves.

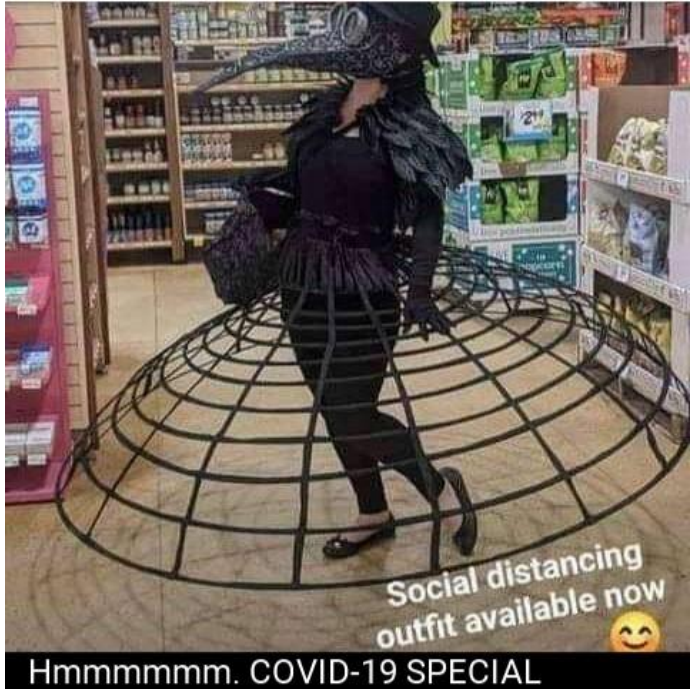

Source: Pinterest 


\subsection{Law Abiding Posts}

Figure 4 presents a commercial cyclist popularly known as 'okada man' in Nigeria.

\section{Figure 4}
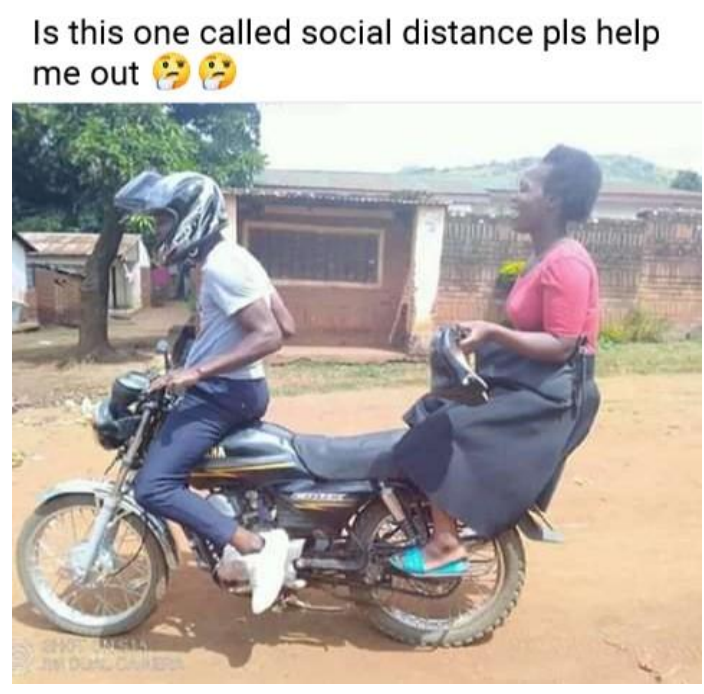

Source: Memes of Uganda
He puts on t-shirt, trousers and tennis shoes, with helmet on his head. The okada man carries a woman who sits at the extreme of the bike's seat; she carries a pair of shoes in her hand; puts on blue palm sandals and she is crying. The okada man sits very close to the motorcycle's handles. The intention of these people is to obey social distancing law because the okada man cannot withstand social distancing law, and he needs to

find a means to earn a living. Likewise the woman sitting on the motorcycle is forcing herself to go to shop or market. The way these people engage themselves on the motorcycle shows that they are law abiding but at the same time having negative experience. This is justified by the caption 'is this one called social distancing? pls help me out? (is this one called social distancing? please help me out). The two emojis accompanying the caption also show the psychological and physiological effects of their experience. The pragmatic act of condoling helps the people adapt to the current situation.

Figure 5 presents a young pastor dressed in white clothes, with a face mask covering both his head, nose and mouth.

The background of the picture foregrounds an altar in a church, and the caption 'Happy Sunday to every one of us: Always obey ur government and put extra obedient to it this, is one of the example' (Happy Sunday to every one of us: Always obey your Government and be obedient by following this example). Ever since Federal Government of Nigeria declared total lockdown, churches and mosques were also instructed to be closed. No congregation is allowed to attend church or mosque. 


\section{Figure 5}

Happy Sunday to every one of us :-

Always obey ur government and put extra obedient to it this is one of the example

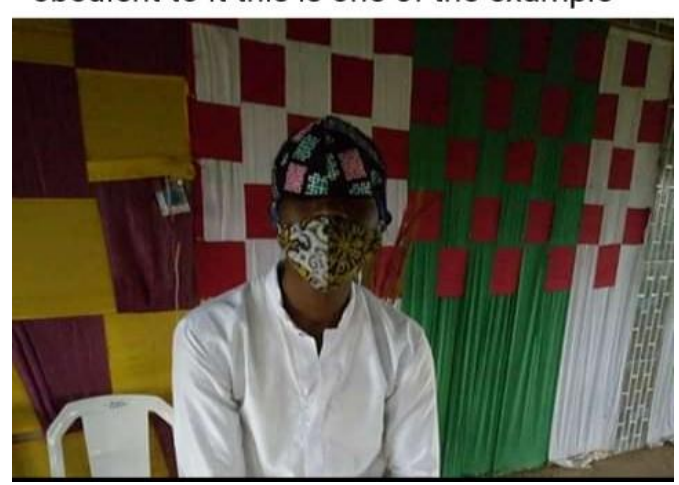

By so doing, this particular Nigerian pastor posted on his Facebook wall to further encourage both his friends and congregation to obey Government's law and COVID-19 pandemic health precautions. Although the health precautions given by WHO and NCDC did not specify the wearing of cap, but this pastor in his obedience and the choice of 'extra obedience' is evident of the cap he puts on. The pragmatic act of figure 5 is demonstrative act.

Source: funny_african_pics

In addition, figure 6 presents two couple clothed in wedding attires.

\section{Figure 6}

They put on green face mask and kiss each other. As part of efforts made by Federal Government of Nigeria in conjunction with World Health Organisation (WHO) and Nigeria Centre for Disease Control (NCDC) to stop the spread of COVID-19 pandemic, social distancing is banned. This ban on social gathering makes it difficult for people to engage in burial ceremony, naming ceremony, birthday party, wedding ceremony and other events. Though the law allows the couples and the clergy man to come together for the holy solemnisation, it does not give room for haptic interaction. If the bride and

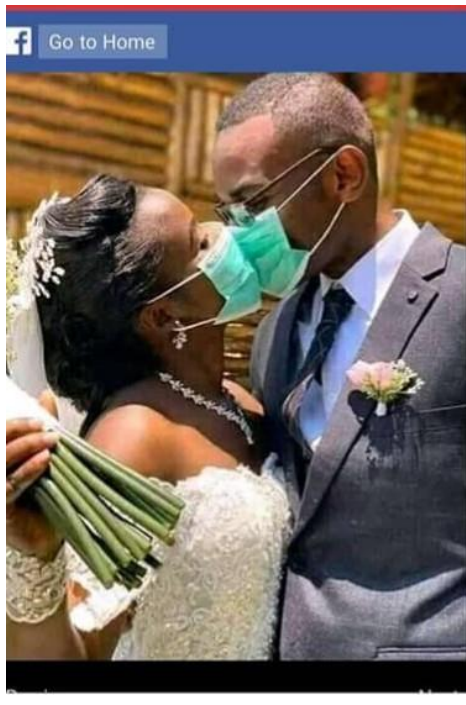

Source: Ghana Jokes laid down rules and regulations. We can see the couple kissing each other by putting on their facemasks. The pragmatic act of this post is demonstrative. It demonstrates how the couples abide by the COVID-19 pandemic health precaution. 


\subsection{Poverty Striking Posts}

These are posts that reflect Nigerians' abject poverty condition. Whenever Nigerians find themselves in difficult situation they try to improvise (Okoroafor \& Neaeze, 2013).

Figure 7 presents two men dressed in white and ashes colours underwears.

\section{Figure 7}

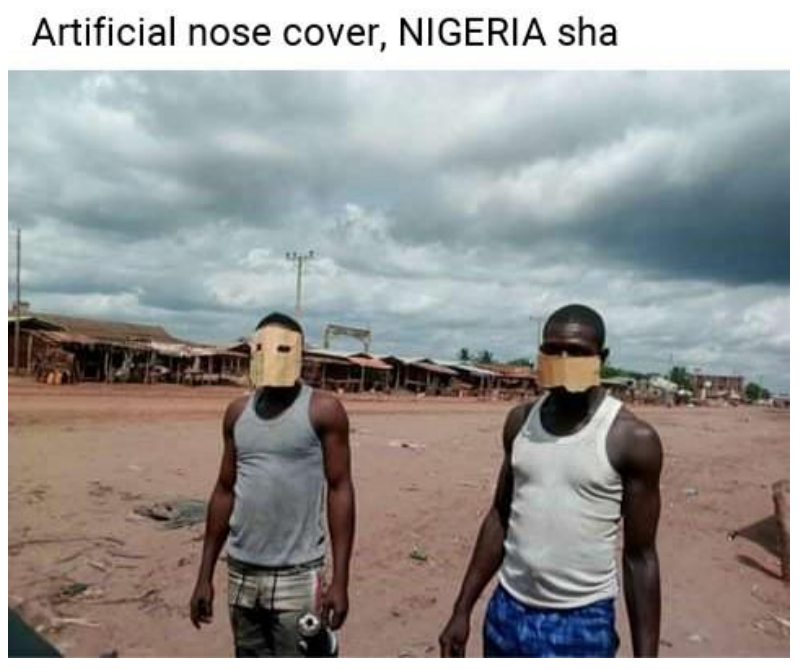

Source: funny_african_pics
The two men put on paper face masks- one covering the entire face and the other one covering both mouth and nose. The background of the pictures is a market place. The pictures show that many Nigerians find it difficult to feed themselves every day let alone talk of getting money to buy face mask. In order for these men to obey government law on COVID-19, they came out with paper face masks. The pictures therefore reveal that many Nigerians are ready to obey COVID-19 pandemic health NIGERIA Sha! (Artificial nose cover, NIGERIA indeed!) shows that Nigerians are ready to adapt to difficult situation. The pragmatic act of this post is suppository act. The people made an attempt to console themselves by adapting the problems emanating from this corona virus pandemic health precaution.

Figure 8 presents a man who puts on plastic face mask. He designed this facemask from an empty gallon. 


\section{Figure 8}

The caption 'creative or stupid?' (Creativity or stupidity?) shows that Nigerians can be creatively stupid when it comes to innovation. One can see this innovation stupid but the design is performing same function with the imported face marks in Nigeria. It therefore shows that Nigerians state of poverty does not stop them from obeying government law. The inscription 'STAY HOME, STAY SAFE' written on the plastic face mask is evident of obedience to government law. The use of capital letter for the inscription shows emphasis on the part of Nigerians to keep or obey social distancing law. Again, the pragmatic act is suppository.

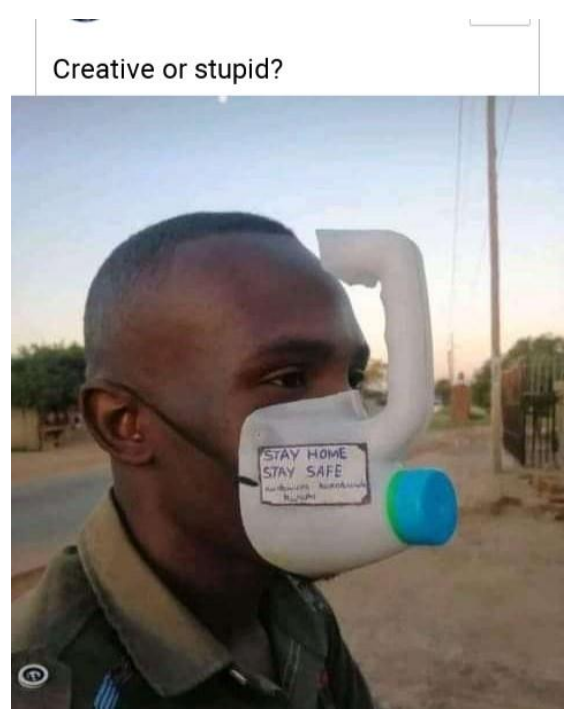

Source: Naijaloaded

\subsection{Satirical Posts}

Figure 9 presents different kinds of shoes which are put on by two unidentified people.

The shoes are so long that they are ludicrously used to obey social distancing.

\section{Figure 9}

Perfect shoes for social

Distancing

\#Covid_19

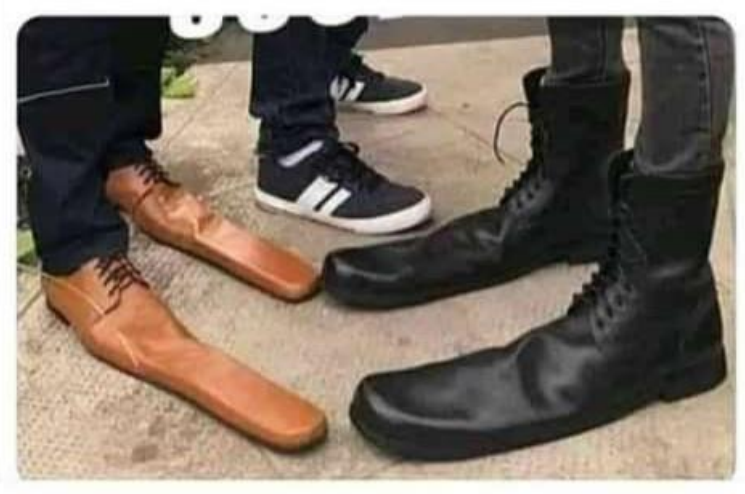

Source: Bad and Bougie Fashion
The inscription 'perfect shoes for social Distancing \# Covid-19' shows that these shoes are designed to exaggerate COVID-19 social distancing law. It can be seen that the two pairs of shoes are put on facing one another to create the actual distance given by WHO and NCDC for social distancing. The design of these shoes creates laughter because nobody can never put on that kind of shoes. Here, the picture presents condoling act because Nigerians are ready to accept their fate. 
Figure 10 shows the interior part of students' hostel.

\section{Figure 10}

In the room, there are germinating yams, grater, pots, plastic buckets, pail, spoon, and bucket of rice all placed on carpet. The picture shows what will happen if COVID-19 lockdown did not stop on time and students' foodstuffs will get spoiled. These germinating yams are evident of the protracted lockdown. The pragmatic act of these pictures is demonstrative. The pictures are demonstrating the effects of indefinite lockdown of the tertiary institutions. The inscription 'How some students room go be after returning back to school' (How some students' room will look like when they resume back to school). The inscription written in Pidgin English makes the text appropriate as it supports the nonverbal modes. The pragmatic

How some students room go be after returning back to school

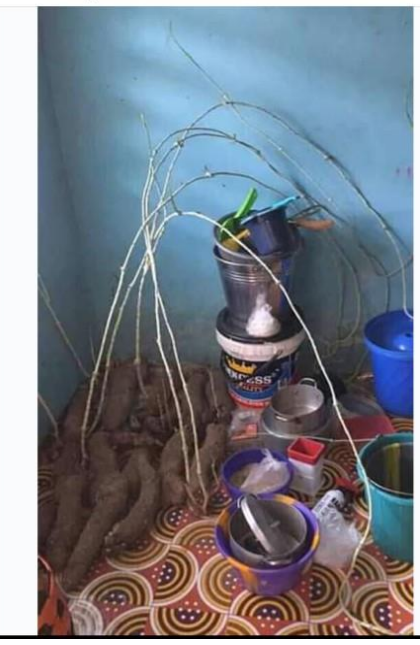

Source: funny_african_pics act is suppository.

Figure 11 shows a young man tying a fairly used pot on his face.

\section{Figure 11}

Please can someone give me his home town

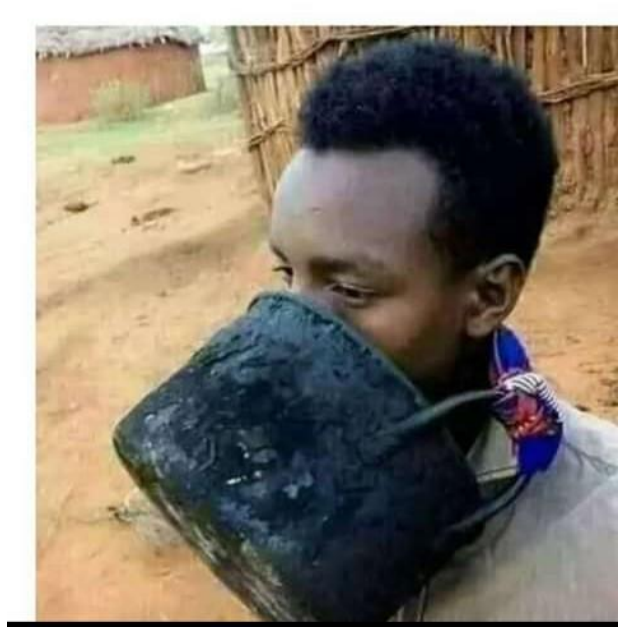

Source: Jokes vs comedy
The man is standing, and the background of the picture shows a rustic setting with a thatched house and wooden wall. The picture shows the abject poverty ravaging the people living in the rural parts of Nigeria. It also shows that Federal Government of Nigeria does not consider the lives of its citizenry. The law is passed without giving appropriate consideration to the poor. Many Nigerians find it difficult to buy face mask for their use. In order for them to obey government ban on movement, they improvise a means to cover their face with pot. Although this picture looks satiric, it portrays poverty. The inscription 'please can someone give me his 
home town?' implies that the young man is not only in need of face mask but wishes to get food from any home. It therefore supports the Yoruba hyperbolic expression 'òlé jelè' (that is, somebody that eats a lot- a glutton). The aroma from the pot he ties on his mouth and nose appropriately supports the inscription. The picture therefore plays a suppository act.

\section{Figure 12}

Figure 12 presents two sections of Isolation Centresone UK and the other, Nigeria.

The United Kingdom Isolation Centre shows a COVID-19 patient who is receiving treatment with different testing kits and standard equipment. The Nigerian Isolation Centre shows a COVID-19 patient who sits on the bed eating with different plastic plates of food and bottled water in his hand. The other section of Nigeria Isolation Centre shows other patients playing with themselves. The intended meaning of these pictures is to compare Nigeria Isolation Centre with the UK's Isolation Centre. It reveals that Nigerians do not believe in the existence of COVID-19.

Covid-19 Patient in UK and Covid-19 Patient in Nigeria (a) Nigeria Why $*$ NCDC I live u people with EFCC

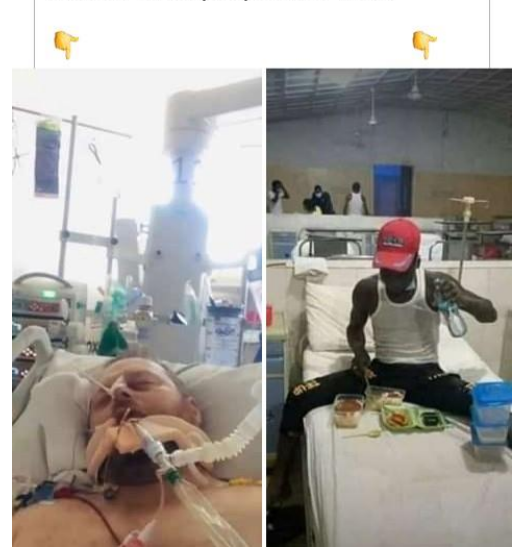

Source: Nairaland Forum The Nigerian patients are isolated to eat to their fill. From Nigeria section of Isolation Centre, there is insufficient equipment. This therefore makes the inscription below appropriate.

'Covid-19 patient in UK and Covid-19 patient in Nigeria, Nigeria why?

NCDC I live (leave) u (you) people with EFCC'

The inscription above questions NCDC to give account of the money they have received to buy COVID-19 equipment, and if they are unable to present this analysis, they will be handed over to Economic fraud and crime commission (EFCC). The Pragmatic act of this picture is assertive. This happens because the picture is posted to make caricature of the situation.

Figure 13 shows a luxury bus loaded with COVID-19 passengers and a driver, with one of them holding a red-yellow flag. 


\section{Figure 13}

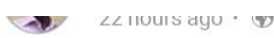

BYE, BYE FOREVER CORONAVIRUS

NIGERIA DOESN'T NEED YOU

In Nigeria people

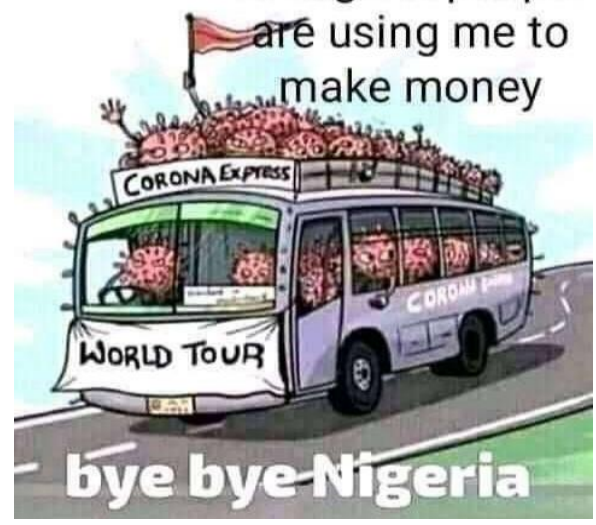

Source: Funny Memes
This picture reveals that COVID-19 pandemic was invented to Nigeria to make money. This claim alludes to the first case of COVID-19 which was recorded in Nigeria to have been brought by an Italian man. The moment corona virus spreads to Nigeria, people started donating money to the government to fight its spread. It is obvious from this picture that Nigerians are tired of this pandemic since on daily basis the number of COVID-19 patents increases and no positive report is coming from NCDC. Nigeria citizens therefore make caricature of the pandemic by suggesting that it goes back to where it came from rather than allowing some Nigerians in power making money.

'BYE, BYE FOREVER CORONA VIRUS

NIGERIA DOESN'T NEED YOU

In Nigeria people are using me to make money

\section{CORONA EXPRESS}

\section{WORLD TOUR'}

The captions above show that Nigerians who cannot share part of this money wish it good bye. Also, 'bye bye Nigeria' is a farewell message from Nigerians. The pragmatic act of this post is assertive.

Figure 14 shows one of the Northern Nigeria isolation centres. 


\section{Figure 14}

\section{COVID-19 PATIENTS FROM GOMBE STATE}

\section{ARE YOU GUYS THINKING WHAT I'M THINKING???? $\theta \theta \theta$}

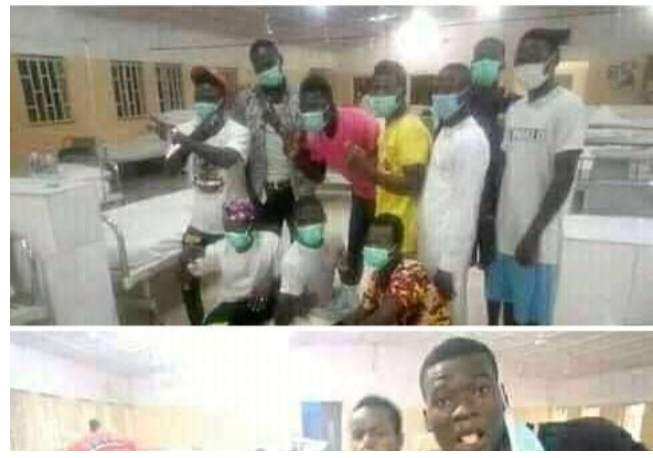

In the picture, COVID-19 patients are taking pictures with different styles. The picture shows that instead of treating COVID-19 patients, they are there to play and make fun. We can see that those people taken as COVID-19 patients are not truly infected by corona virus. They are only taken to isolation centre for merriment. The pragmatic act of this picture is therefore assertive because it is ridiculing Nigeria Government effort to contain corona virus.

Source: Rariya

\section{Figure 15}

Figure 15 presents a young man with a raised placard in which the inscription 'please open our schools we know that corona virus is a SCAM in Nigeria' is written.

The intention of this post shows that Nigerians, most especially students, parents and teachers are tired of 'stay at home, stay safe' instruction. Their reactions here portray that COVID-19 pandemic is not real in Nigeria but a scam. The word 'scam' written in

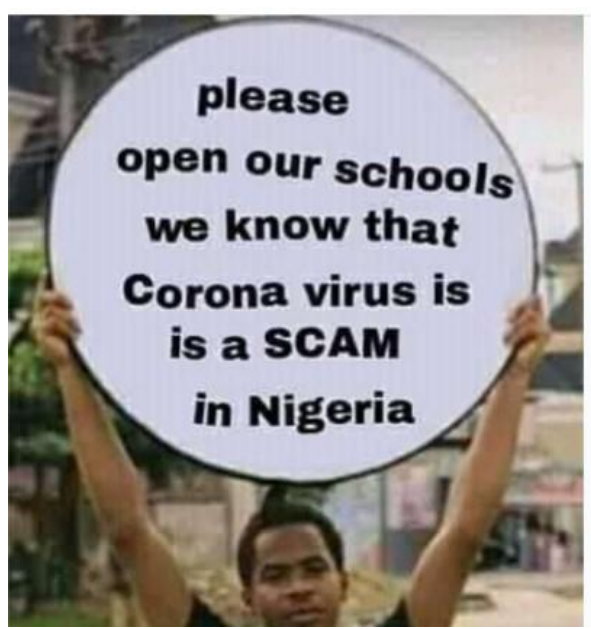

Source: Cocopops post emanated after Federal Government of Nigeria lifted ban on markets and other financial institutions. But primary to tertiary schools remain closed, and this is giving students concern about their education since what is sauce for goose is sauce for the gander. Hence, this picture is demonstrating Nigerians reactions towards COVID-19 pandemic.

In the same vein, figure 16 presents a young man dressed in a mufti, with an aluminum pot attached to an electronic stove on his head. 


\section{Figure 16}

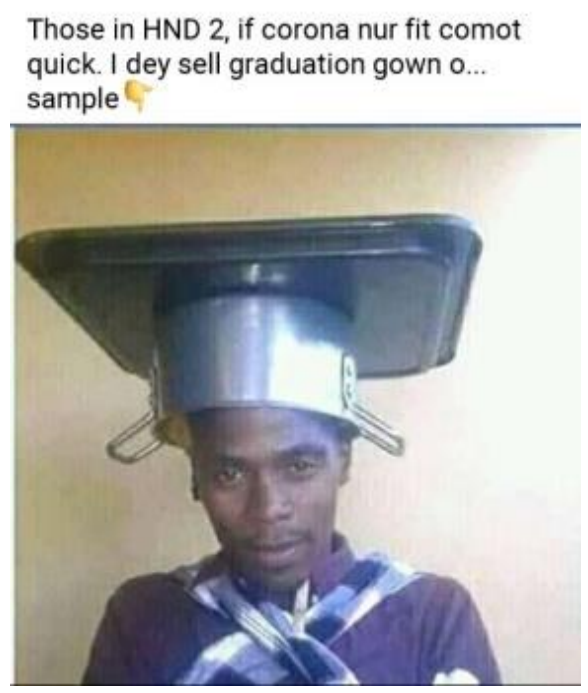

Source: Finfinnee For OROMO
The pot is designed to replace the function of graduation gown. This post is a caricature of Nigeria educational sector, which does not give prominence to education. It is a normal practice in Nigeria for Nigerian students to remain home during nationwide strike which may increase a four-year programme to six or seven years before graduation. It is obvious that COVID-19 pandemic is another form of indefinite strike in educational sector since Nigeria Government does not specify when it will end. To portray Nigerians' reactions towards this indefinite lockdown of schools, the post therefore predicts what will happen to those in final year

of their academic session, that is, those in primary 6, JSS 3, 400L and so on. If one could not complete one's academic programme, one then needs to console oneself with the above graduation gown and cap. We can say that the picture above, which has an inscription 'Those in HND2, if corona but fit comot quick. I dey sell graduation gown o... sample (To those in HND2, if corona virus is not contained on time, I am selling graduation gown. Kindly see this sample) shows an instance of condoling act. The students have ironically appeared to have accepted their fate and get adapted to the current situation.

\section{Conclusion}

This paper analysed the different Nigerians Facebook posts based on their reactions towards COVID-19 pandemic health precautions. The findings showed that different pragmatic acts and nonverbal semiotic resources were deplored to represent their reactions. The posts, which were classified under four semantic fields - business innovation and profit oriented, law abiding, poverty striking and satirical posts have various pragma-semiotic strategies such as creativity, obedience, complacency, begging and ridicule.

The pragmatic acts in the posts include: demonstrative, persuasive, suppository/conjecture, assertive and condoling. The demonstrative acts represent the Nigerians possibility of coming back to their normal lives activities. Persuasive act is 
concerned with the new strategy adopted by Nigerians for making quick sale of their products, and suppository acts present the ironic situations Nigerians found themselves, that is, some Nigerians are meant to obey COVID-19 pandemic health precautions by improvising paper, plastic and fairly used aluminum pot face masks for their use. It is also ironic that Nigerian students who are supposed to finish their academic programme and clothed in a graduation gown did so by putting on electric cooker and pot as cap and graduation gown. In addition, it revealed the ironic situation of Nigeria Isolation Centre compared to that of UK which called for questioning on the part of NCDC and Buhari's administration.

Therefore, this study has established the appropriateness of linguistic and nonlinguistic text choice in relation to each post which portrays Nigerians' reactions for meaning potential. The nonlinguistic texts effectively communicated Nigerians intentions without reading the captions. It was concluded that Nigerians' intentions towards COVID-19 pandemic health precautions are mainly for mockery and possibility of returning to normal lives activities before COVID-19 lockdown.

\section{References}

Alvarez, R. (2020). An alternative approach to COVID-19. International Journal of Scientific \& Engineering Research. 11(4)

Anyanwu, E. C. (2020). Stylistic analysis of President Buhari's addresses of Nigerians in the face of COVID-19 pandemic. European Journal of English language and Literary Studies 8(4), 14-27.

Aliya, I. (2021). Pragmatic stance in selected Nigerian newspaper report on covid-19. Paper presented at 4th International Conference/Workshop Pragmatics Association of Nigeria in conjunction with the Department of English and Literature, University of Benin on the theme: Pragmatics and Global Conflicts, 8th-11th February, 2021.

Ayeni, A.C. (2021). Conflictual epistemic orientation: A pragmatic investigation of covid-19 realities in Nigeria. Paper presented at 4th International Conference/Workshop Pragmatics Association of Nigeria in conjunction with the Department of English and Literature, University of Benin on the theme: Pragmatics and Global Conflicts, $8^{\text {th }}$ 11th February, 2021.

Cheng, L. (2020). Institutional and news media denominations of COVID-19 and its causative virus: between naming policies and naming politics. Discourse \& Communication, 14(6), 635-652. 
Chiedu, R. E. (2021). Pragmatic analysis of the vocabulary of corona virus (Covid-19/ in Nigeria. Paper presented at 4th International Conference/Workshop Pragmatics Association of Nigeria in conjunction with the Department of English and Literature, University of Benin on the theme: Pragmatics and Global Conflicts, 8th-11th February, 2021.

Grzelka, M. (2020). Attitudes toward vulnerable populations in the time of COVID-19: Critical discourse analysis of Gazeta. PL online comment sections. Society Register 4 (2), 121-132. doi: 10.14746/St. 2020.4.2.09

Halliday, M. A. K. (1978). Language as a social semiotics: The social interpretation of language and meanings. London: Edward Arnold.

Kalejaiye, A.S. (2021). A cross-cultural pragmatic study of politeness strategies in the covid19 advertisements of native English speakers versus non-native speakers. Paper presented at the 4th International Conference/Workshop Pragmatics Association of Nigeria in conjunction with the Department of English and Literature, University of Benin on the theme: Pragmatics and Global Conflicts, 8th-11th February, 2021.

Kress, G., \& van Leeuwen, T. (2006). Reading images: The grammar of visual design. London Routledge.

Kress, G., \& van Leeuwen, T. (2001). Multimodal discourse: The modes and media of contemporary communication. London: Arnold.

Mey, J. L. (2001). Pragmatics: An introduction. Malden, Oxford: Blackwell Publishing.

Nnadozie, E. (2002). African indigenous entrepreneurship determinants of resurgence and growth of Igbo entrepreneurship during the post-Biafra period. Journal of Business, 3(1), 49-80. doi: 10.1300/JI56vo3nO1_04

Okoroafor, M. O., \& Nwaeze, C. (2013). Poverty and economic growth in Nigeria 19902011. The Macrotheme Review, 2(6), 105-115.

Oladapo, S.O., Oladapo, I.P., \& Badamosi, T.Z. (2020). COVID-19 pandemic: Rural dwellers towards eradication in .Cape Comorin: An International Multidimensional Double-Blind Peer -Review Journal, Special Issue, 11(IV).

Onyema, C. C. (2021). A Pragmatic-stylistic study of selected presidents' speeches at the outbreak of corona virus. Paper presented at the 4th International Conference/Workshop of Pragmatics Association of Nigeria in conjunction with the Department of English and Literature, University of Benin on the theme: Pragmatics and Global Conflicts, 8th-1 $1^{\text {th }}$ February, 2021.

Olorunsogo, D., \& Olufaso, I.O. (2021). 'We fall under essential services': Representations of sexworkers and identity in online newspaper reports of covid-19 lockdown in Nigeria. Paper presented at 4th International Conference/Workshop Pragmatics Association of Nigeria in conjunction with the Department of English and Literature, University of Benin on the theme: Pragmatics and Global Conflicts, 8th-11th February, 2021.

Olaniyi, O.K., \& Atolagbe, O.D. (2021). A pragmatic inquiry into the private schools lived experiences in relation to Covid-19 lockdown in Nigeria Paper presented at the $4^{\text {th }}$ 
International Conference/Workshop Pragmatics Association of Nigeria in conjunction with the Department of English and Literature, University of Benin on the theme: Pragmatics and Global Conflicts, 8th-11th February, 2021.

Ononye, C. F., \& Offor, M.C. (2021). "No wonder people are afraid of corona virus": Rhetorical strategies and fear steering in government media sensitisation messages on Covid-19. Paper presented at 4th International Conference/Workshop Pragmatics Association of Nigeria in conjunction with the Department of English and Literature, University of Benin on the theme: Pragmatics and Global Conflicts, 8th-11th February, 2021.

Predia, K. C. (2021). The place of humorous memes amidst the Covid-19 pandemic and how these help to ameliorate the hardships suffered by citizens. Paper presented at the $4^{\text {th }}$ International Conference/Workshop Pragmatics Association of Nigeria in conjunction with the Department of English and Literature, University of Benin on the theme: Pragmatics and Global Conflicts, 8th-11th February, 2021.

Prieto-Ramos, F., PEI, J., \& Saidu,T. U. (2020). COVID-19 pandemic: A sociological perspective in Nigeria. Continental Journal of Arts and Humanities, 12(1), 1-14.

Sasot, C. F., Nicomedes, C. J. C., Marcos, R. G., Perez, A. D., Agaman, J. B., Fernando, M. M. M. (2020). A discourse analysis on class cancellation during the covid-19 pandemic. doi:10.13140/RG. 2.2.34571.03364

Tan, J. (2020). COVID-19 survival guide- The Singapore experience: Jesslyn Tan.

Ugoala, B. (2021). Covid-19 and the Nigeria situation: A multimodal discourse analysis of selected cartoons. Paper presented at 4th International Conference/Workshop Pragmatics Association of Nigeria in conjunction with the Department of English and Literature, University of Benin on the theme: Pragmatics and Global Conflicts, 8th11th February, 2021.

Uwadiegwu, C. U. I. (2021). President Trump's speeches on covid-19: A socio-pragmatic study. Paper presented at 4th International Conference/Workshop Pragmatics Association of Nigeria in conjunction with the Department of English and Literature, University of Benin on the theme: Pragmatics and Global Conflicts, 8th-11th February, 2021.

Yahaya, S. (2021).Threat construction and fear appeals in President Buhari's war rhetoric on Covid-19 in Nigeria. Paper presented at 4th International Conference/Workshop Pragmatics Association of Nigeria in conjunction with the Department of English and Literature, University of Benin on the theme: Pragmatics and Global Conflicts, 8th$11^{\text {th }}$ February, 2021. 